\title{
Conhecimento, Escola e Cultura(s) - Perspectivas que se entrelaçam
}

A primeira edição da e-Mosaicos - Revista Multidisciplinar de Ensino, Pesquisa, Extensão e Cultura do Instituto de Aplicação Fernando Rodrigues da Silveira (CAp-UERJ) deste ano traz ao leitor algumas novidades e, também, modificações.

A reestruturação de nossa revista se materializa exatamente no ano em que o Instituto de Aplicação Fernando Rodrigues da Silveira completa sua sexta década de existência e, por isso, as capas deste ano se constituirão, também, como uma homenagem a esta Unidade Acadêmica da Universidade do Estado do Rio de Janeiro que tem como foco a formação de professores em nível de graduação e de pós-graduação e a educação básica, sempre primando pela excelência em suas diferentes frentes de atuação no campo do ensino, da pesquisa e da extensão universitária.

A partir de 2017, e-Mosaicos passa a ser uma revista quadrimestral e, dessa forma, optamos por publicar no mínimo uma edição temática por ano, sendo a mesma organizada pelo próprio Conselho Editorial ou por convidados, acolhendo também propostas que nos cheguem e que dialoguem com a perspectiva da revista.

Nesse movimento, esta edição aborda a temática "Conhecimento, escola e cultura(s)", a partir de uma proposição feita pelos professores Luis Paulo Cruz Borges (UERJ) e Paula Almeida de Castro (UEPB) e traz para a nossa reflexão artigos que abordam as interfaces entre os aspectos que dão título à edição, considerando diferentes realidades, no Brasil e para além de seu território e contextos. Permite perceber os lugares de professores pesquisadores, tão fundamental nas práticas pedagógicas desenvolvidas em diferentes lugares do mundo, com sua diversidade cultural e com diferentes jeitos de ser e de fazer cotidianamente a educação e as escolas e, assim, produzir conhecimentos.

$E$ antes de concluir esse editorial registramos uma notícia que muito nos alegrou no final do ano de 2016, dando ares de renovação para um ano extremamente difícil na história da nossa Universidade. O resultado do QUALIS/CAPES periódico para o quadriênio 20122015 atribuiu qualificação B1 na área de Ensino para a e-Mosaicos. Além disso, a revista também recebeu sua primeira qualificação nas seguintes áreas: B4 em Ciência Política e Relações Internacionais e B5 nas áreas de Geografia, História e Sociologia.

Agradecemos a cada autor que acreditou no potencial da e-Mosaicos e também a cada membro do Conselho Editorial e da equipe de pareceristas ad hoc que vem tecendo esse mosaico, parte a parte, a cada edição.

Convidamos novos autores a continuarem a escrever essa história junto conosco, por acreditarmos que na diversidade e por meio da interface com diferentes atores e instituições, seguimos mais fortes na caminhada de divulgação da ciência produzida nos espaços escolares, seja por meio das pesquisas ou das práticas docentes nos campos do ensino e da extensão universitária.

\section{Andrea da Paixão Fernandes}

Débora de Aguiar Lage

Editoras da e-Mosaicos - Revista Multidisciplinar de Ensino, Pesquisa, Extensão e Cultura do Instituto de Aplicação Fernando Rodrigues da Silveira (CAp-UERJ) 